
Iulius CRISTEA

Principiile arhitecturii clădirilor hoteliere

The principles of hotel buildings' architecture

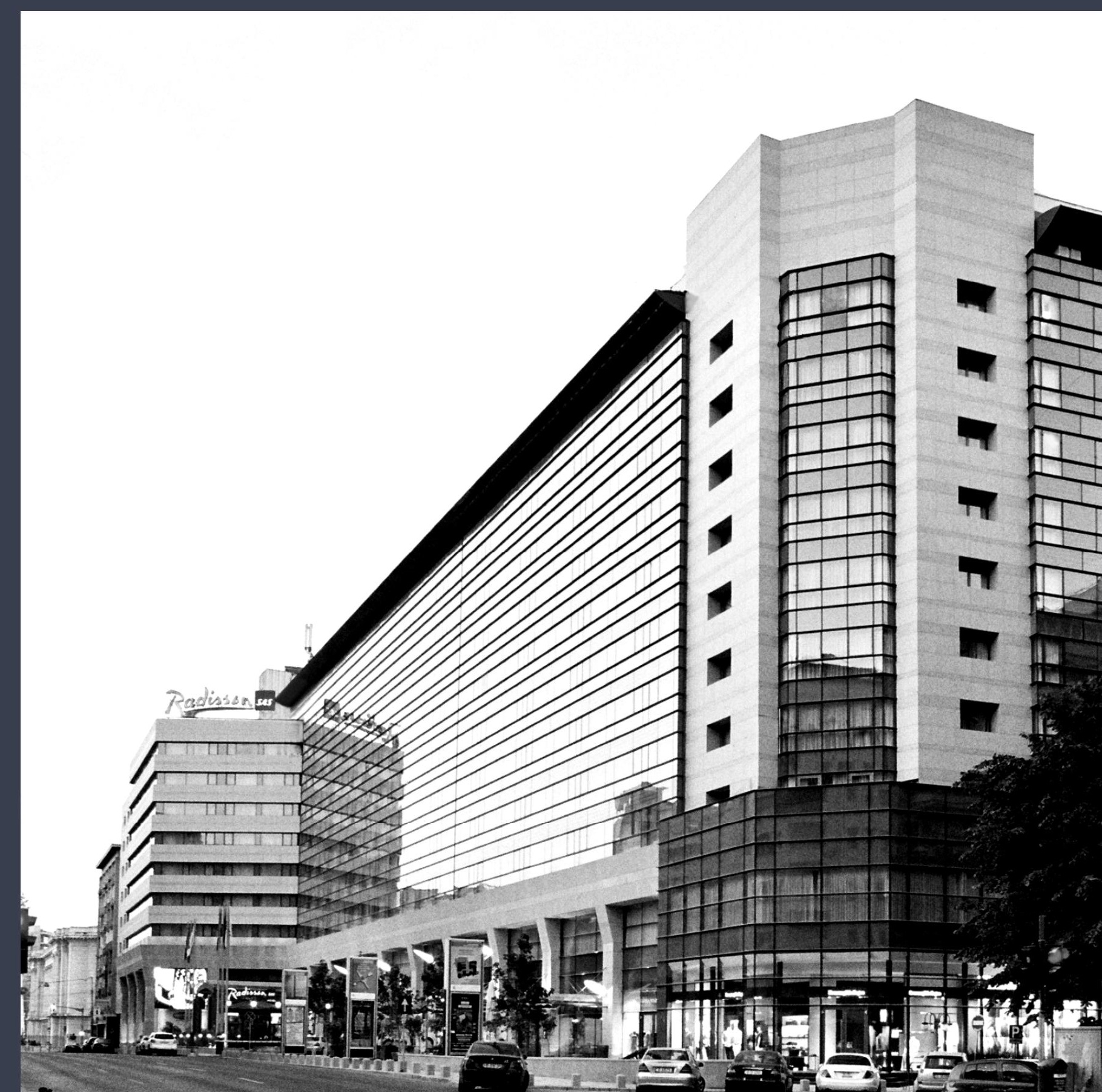




\section{Principiile arhitecturii clădirilor hoteliere}

The principles of hotel buildings' architecture

lulius CRISTEA

iuliuscristea@yahoo.fr

Conf. Dr.Arhitect, SP*, FA UAUIM Assoc.Prof. Dr.Architect, SP*, FA UAUIM

*Departament Sinteza Proiectării de Arhitectură Facultatea de Arhitectură Universitatea de Arhitectură și Urbanism lon Mincu UAUIM București *Synthesis of Architectural Design Department (SP) Faculty of Architecture Ion Mincu University of Architecture and Urbanism
Hotelul este un program de arhitectură comercial prin excelență. Pentru ca afacera să aibă succes, serviciile oferite trebuie să fie de calitate, la costuri de operare optimizate. Pentru clienti, călatoriile sunt adesea asociate cu ieșirea din rutină, iar calitatea cazării joacă un rol important în reușita acestora.

Dacă pentru un hotel mic atmosfera, detaliile și atitudinea personalului pot să compenseze anumite disfuncțiuni, la hotelurile mari, gestionate de operatori internaționali, standardele de proiectare sunt foarte stricte, clădirile trebuind sa răspundă unor criterii de eficientă și confort, în functie de clasificarea lor, exprimată într-un număr de stele, de la unu la cinci, în general.

cuvinte cheie

hotel, principii, arhitectură, cercetare prin proiect, practică profesională abstract

The hotel is a commercial architectural program, 'par excellence'. For the business to be successful, the services must be of quality with optimized operating costs. For the guests, travelling takes them out of their everyday routine, and the quality of accommodation plays an important role of their stay.

If for a small hotel the atmosphere, details and attitude of the staff can compensate for certain malfunctions, in the big hotels, managed by international operators, the design standards are very strict, the buildings have to meet criteria of efficiency and comfort, according to their classification, expressed in a number of stars, from one to five, in general.

keywords

hotel, principles, architecture, research-by-design,

professional practice 
Derivat din latinescul hospitalis, cuvântul hotel desemnează o clădire cu multe camere mobilate destinate închirierii, cu ziua, călătorilor. Este o noțiune familară, iar reprezentarea sa poate lua forme foarte variate, în funcție de situarea și de gradul de confort al fiecărei clădiri, de la moteluri, până la hotelurile luxoase din marile orașe sau din stațiunile turistice.

Hotelul este un program de arhitectură comercial prin excelență. Pentru ca afacera să aibă succes, serviciile oferite trebuie să fie de calitate, la costuri de operare optimizate. Pentru clienți, călatoriile sunt adesea asociate cu ieșirea din rutină, iar calitatea cazării joacă un rol important în reușita acestora.

Din punctul de vedere al investitorului, amplasarea unui hotel trebuie să țina cont de valențele sitului: locații centrale cu acces facil și vad comercial, raportul dintre cererea și oferta de unitați de cazare în zona, calitățile peisagere ale locului, etc.

Din punctul de vedere al arhitectului, ca orice altă clădire, hotelul trebuie abordat de manieră holistică, tinând cont de aspectele urbane, economice, funcționale, estetice, tehnice etc. Proiectarea unui hotel se face în funcție de caracteristicile terenului, de constrângerile reglementărilor urbanistice și de nivelul de confort propus. De acesta din urmă depinde mărimea și numărul unităților de cazare, de diversitatea funcțiunilor conexe (restaurante, săli de mic dejun, cafenea, bar, săli de conferințe, zone de loisir și de relaxare). Hotelurile mari și de standard ridicat pot deveni repere urbane, iar cele mai modeste se pot insera discret în context.
Fig.1* Hotel Radisson Blu, București, Cristea Arhitectură, 2007 / Radisson Blu Hotel, Bucharest, architect(s): Cristea Arhitectură,

Fig.2* Hotel Park Inn, București, Cristea Arhitectură, 2015 / Park Inn Hotel, Bucharest, architect(s): Cristea Arhitectură, 2015

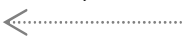

*Imagini: autorul articolului, Cristea I. / Images: article's author Cristea l.

Este destul de des întâlnit conceptul de hotel boutique, potrivit căruia, în pofida dimensiunilor reduse ale clădirii, hotelul oferă condiții de lux.

Dacă pentru un hotel mic atmosfera, detaliile și atitudinea personalului pot să compenseze anumite disfuncțiuni, la hotelurile mari, gestionate de operatori internaționali, standardele de proiectare sunt foarte stricte, clădirile trebuind sa răspundă unor criterii de eficiență și confort, în funcție de clasificarea lor, exprimată într-un număr de stele, de la unu la cinci, în general.

Unitățile de cazare definesc în cea mai mare măsură gradul de confort al unui hotel.

Dimensiunile și suprafețele lor sunt normate de standardele de clasificare. Calitatea luminii naturale și artificiale, a detaliilor, a designului mobilierului ș grupului sanitar vor fi în concordantă cu nivelul de clasificare al ansamblului.

Accesul principal trebuie să fie vizibil, situat pe poziția cea mai favorabilă. Accesul personalului și a mărfii trebuie să fie disimulat, orientat către străzi secundare, dar care să permită o aprovizionare cu vehicule utilitare. 
Holul central este caracterizat de o anumită generozitate și polivalență, putând fi folosit simultan de oaspeții care așteaptă să se cazeze cât și de cei deja cazați sau alți vizitatori. Holul poate fi un spațiu în care fuzionează mai multe funcțiuni, precum accesul, recepția, zona de așteptare, barul, zona de mic dejun etc. Recepția trebuie să se afle în imediata apropiere a intrării, cu o foarte bună vizibilitate.

În mare, din punct de vedere funcțional, se disting două zone, a căror tratare este total diferită: cele la care publicul are acces și cele la care doar personalul hotelului are acces.

Zonele destinate publicului sunt menite să flateze simțurile, căutându-se o ambianță cât mai plăcută, iar cele pentru personal trebuie să fie caracterizate prin funcționalitate și eficiență, răspunzând unor exigențe ridicate în materie de sigurantă și igienă.

Din punct de vedere funcțional, este necesară o dispunere logică a unităților de cazare, care să reducă lungimea circulațiilor și să permită condiții de însorire și vederi cât mai avantajoase în camere. Zonele de alimentație publică și relaxare vor pune în valoare calitățile sitului, oferind un grad de reprezentare optim.

Raportul dintre suprafețele spațiilor servite și ale celor servante va fi favorabil celor dintâi. Suprafețele circulațiilor vor fi minimizate, păstrând totuși o oarecare generozitate, corespunzătoare cu gradul de confort al hotelului și cu normele de accesibilitate a persoanelor cu mobilitate redusă și de securitate la incendiu.

Pentru o mai mare atractivitate, funcțiunile de cazare și alimentație publică sunt completate cu săli de conferințe, localuri comerciale de tip boutique, săli pentru evenimente, centre gimnastică, piscine etc.

La hotelurile mari, zonele destinate personalului pot fi destul de dezvoltate: există bucătării cu depozitările aferente, vestiare, birouri, arhive, spălătorii, zone de acces și descărcare a mărfii, parcaje subterane, zone de depunere și sortare a deșeurilor, centrale termice și de ventilație, generatoare, rezerve de apă și combustibil, posturi de transformare, adăposturi de protecție civilă, etc. Unele din aceste funcțiuni se pot situa în subsol, altele pot $\mathrm{fi}$ orientate către spații exterioare secundare, iar unele se pot afla deasupra clădirii, precum echipamentele tehnice de ventilație. Un hotel contemporan poate $\mathrm{fi}$ comparat $\mathrm{cu}$ un pachebot: pentru ca la bord ambianța să fie cât mai plăcută, în cală lucrează o adevărată uzină. Publicul nu este nevoit să conștientizeze activitatea din culise.

În general, hotelurile au cel putin două noduri de circulație verticală, unul destinat publicului, cu o baterie de lifturi și scări de evacuare, iar celălalt, secundar, cu lift de marfă, pentru serviciul în cameră (room service) și scări de evacuare în caz de urgentă. Pe fiecare hol de etaj se prevăd oficii pentru personal, unde se depozitează lenjeria și materialele pentru curățenie.

Fig.3* Hotel Radisson Blu, București, Cristea Arhitectură, 2007 / Radisson Blu Hotel, Bucharest, architect(s): Cristea Arhitectură, 2007 ……............

*Imagini de la autorul articolului, Cristea I. / Images from the article's author, Cristea I. 


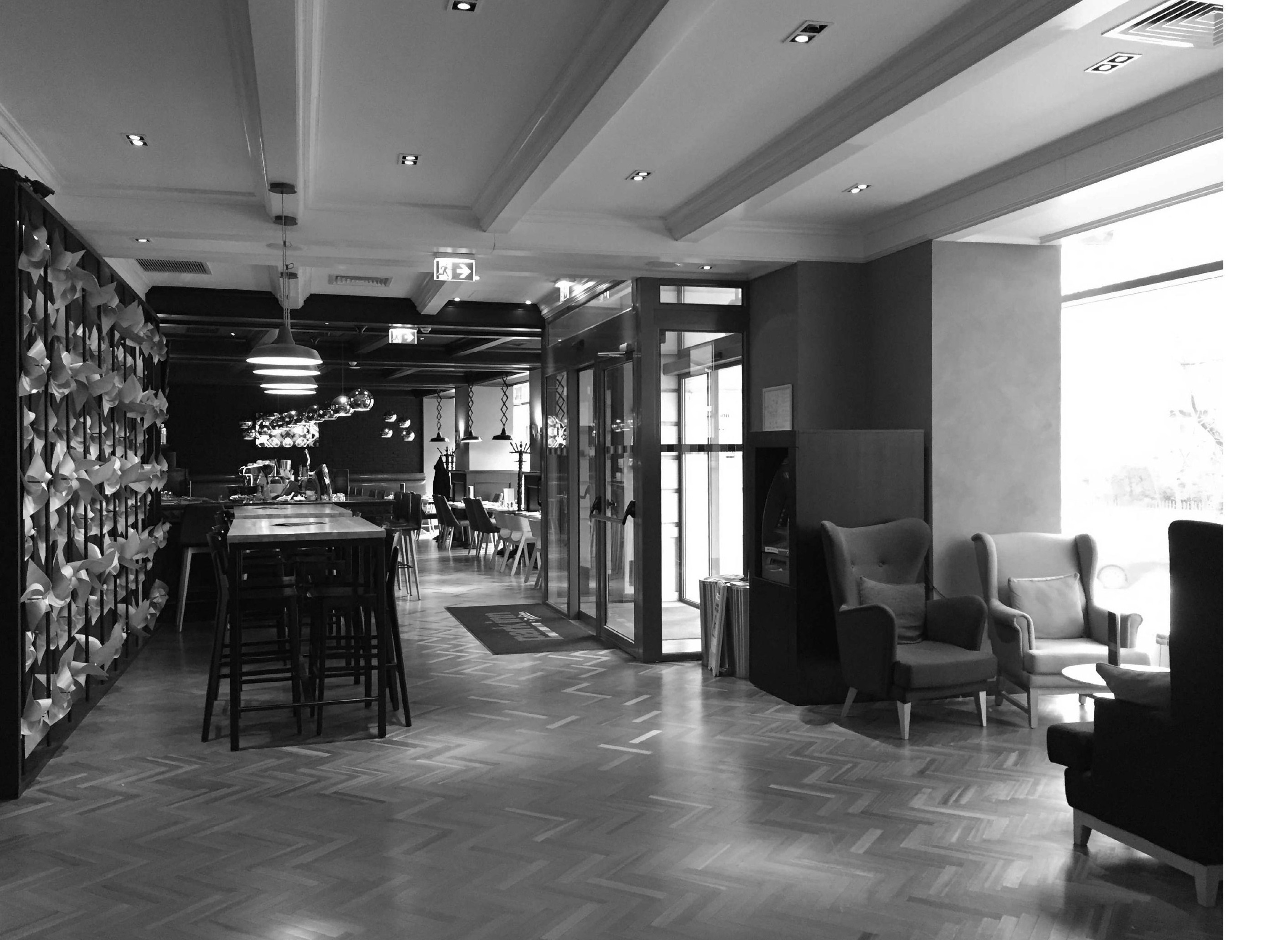


Fig.4* Hotel Park Inn, București, Cristea Arhitectură, 2015 / Park Inn Hotel, Bucharest, architect(s): Cristea Arhitectură, 2015

Fig.5* Apartament de închiriat în București, Cristea Arhitectură, 2020 / Apartment for rent, Bucharest, architect(s): Cristea Arhitectură, 2020

Fig.6* Apartament de închiriat în București, Cristea Arhitectură, 2020 / Apartment for rent, Bucharest, architect(s): Cristea Arhitectură, 2020

*Imagini de la autorul articolului, Cristea I. / Images from the article's author, Cristea I.

Relativa standardizare a unităților de cazare face ca arhitectura hotelieră să fie marcată de o anumită repetitivitate, hotelulrile fiind destul de ușor de reperat în peisaj.

Din punct de vedere al tratării arhitecturale, hotelurile pot avea conturate anumite trăsături distinctive. Ele pot fi reprezentative în același timp pentru marca pe care o reprezintă și pentru locul în care sunt situate. Fiind marcate de spiritul locului, ele pot fi ușor identificate cu destinația propusă. Formele arhitecturale, materialele, culorile, texturile, iluminarea naturală și artificială, acustica, stimulii tactili si olfactivi, formează un întreg care determină calitatea experienței arhitecturale.

Din punct de vedere tehnic, pentru a asigura eficiența investiției, soluțiile constructive vor fi cât mai simple și economice. O concepție logică a structurilor reduce investiția inițială. Izolarea bună a anvelopantei, randamentul ridicat al instalațiilor, automatizările privind consumul de energie electrică în lipsa utilizatorilor, contribuie la reducerea cheltuielilor de exploatare.

O bună izolare fonică reprezintă un aspect foarte important, în ceea ce privește confortul și oferă posibilitatea unei simultaneițăti a diferitelor activități.

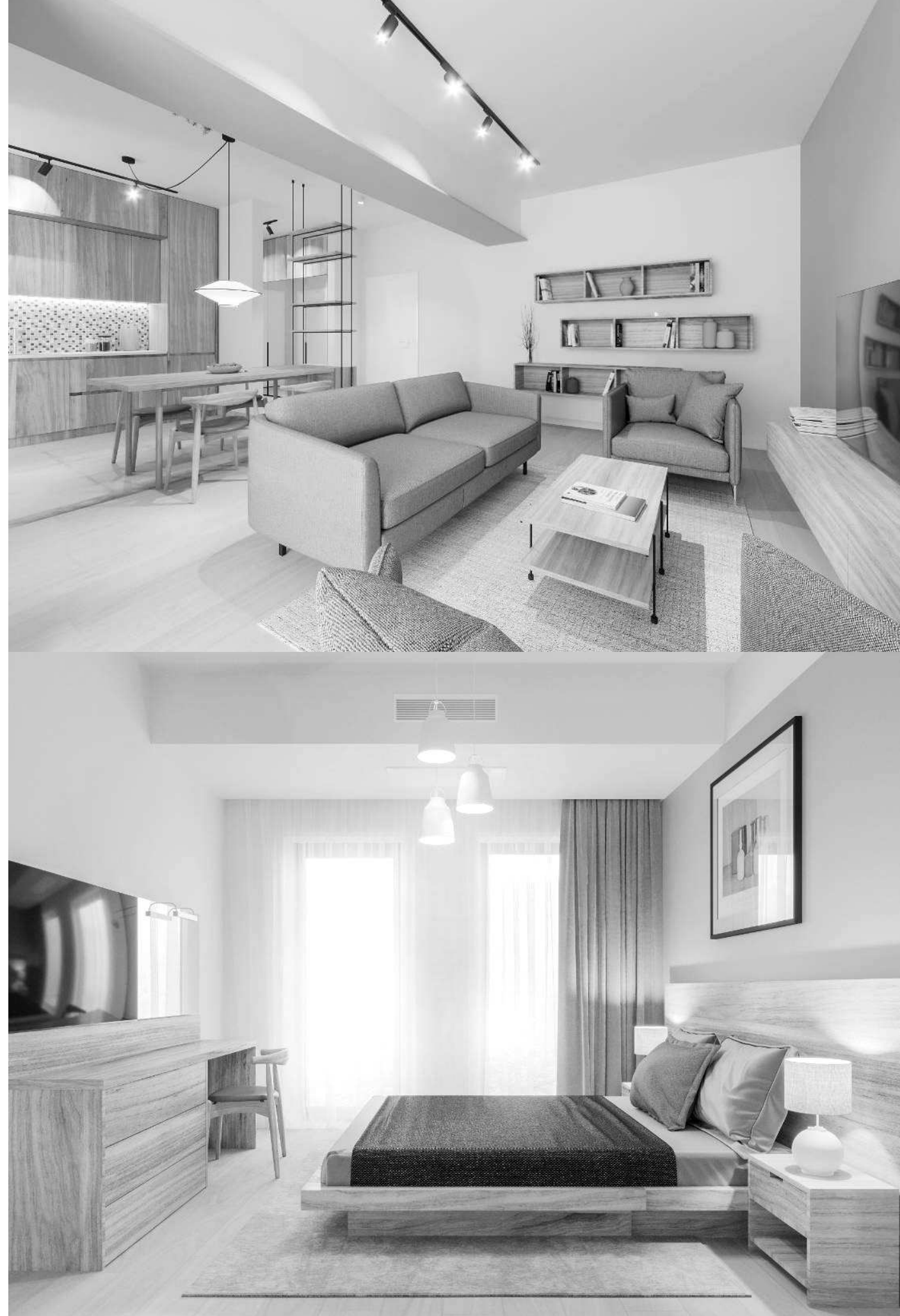


(english version)

Derived from the Latin hospitalis, the word hotel refers to a building with many furnished rooms leased to travelers by day. It is a familiar concept that can be represented through different forms, depending on the location and the degree of comfort of each particular building, from small motels to luxury hotels in big cities or tourist resorts.

The hotel is a program of commercial architecture par excellence. For the business to be successful, the offered services must be of quality, at optimized operating costs. For guests, travel is often associated with routine departure, and the quality of accommodation plays an important role in their success.

From the investor's point of view, the location of a hotel must take into account the valences of the site: central locations with easy access and commercial site, the ratio between the demand and the supply of accommodation units in the area, the landscape qualities of the place, etc.

From the point of view of the architect, like any other building, the hotel must be approached in a holistic way, taking into account the urban, economic, functional, aesthetic, technical aspects etc. The design of a hotel is made according to the characteristics of the site, the constraints given by the city planning regulations and the proposed level of comfort. On the latter depends the size and number of accommodation units, specific also the diversity of the related functions (restaurants, breakfast rooms, coffee shops, bars, conference halls, leisure and relaxation areas). Large and high standard hotels can become urban landmarks, and the most modest ones can be discreetly inserted in context.
The concept of a boutique hotel is quite common, according to which, despite the small size of the building, the hotel offers luxurious conditions.

If for a small hotel the atmosphere, details and attitude of the staff can compensate for certain malfunctions, in the big hotels, managed by international operators, the design standards are very strict, the buildings have to meet criteria of efficiency and comfort, according to their classification, expressed in a number of stars, from one to five, in general.

The accommodation units define the degree of hotel comfort.

Their dimensions and surfaces are regulated by the classification standards. The quality of the natural and artificial light, the details, the design of the furniture and the bathroom will be in accordance with the classification level of the whole ensemble.

The main access must be visible, located in the most favorable position. The access of the personnel and the goods delivery must be concealed, oriented to secondary streets, but allowing a supply of commercial vehicles.

The central hall is characterized by a certain generosity and polyvalence. It has to be be used simultaneously by guests waiting to be accommodated as well as those already staying as customers, or other visitors. The hall can be a space where several functions are merged, such as access, reception, waiting area, bar, breakfast area, etc. The reception should be in the immediate vicinity of the entrance, with very good visibility.

In general, from a functional point of view, two areas are distinguished, which treatment is totally 
different: those to which the public has access and those to which only the hotel staff has access.

Areas intended for the public are meant to flatter the senses, in searching for the most pleasant ambience, and those for the staff must be characterized by functionality and efficiency, meeting high demands on safety and hygiene.

From a functional point of view, a logical arrangement of the accommodation units is needed, which will reduce the length of traffic corridors and permit sunlight conditions and views in the rooms as much as possible. The areas for food, bars and relaxation will highlight the qualities of the site, offering an optimum degree of representation.

The ratio between the areas of the serviced spaces and the servant ones will be favorable to the first ones. The surfaces of the traffic corridors will be minimized, yet maintaining generosity, corresponding to the degree of hotel's comfort and according to the accessibility norms of reduced mobility persons and fire safety regulations.

For enhanced attractiveness, the accommodation and food courts are complemented with conference rooms, commercial premises of boutique type, halls for events, fitness centers, swimming pools etc.

In large hotels, the staff dedicated areas could be quite enlarged: there are kitchens with associated warehouses, changing rooms, offices, archives rooms, laundries spaces, access and unloading goods areas, underground parking areas, waste disposal and sorting centers, thermal power stations and ventilation, generators, water and fuel reserves, electric transformer stations, civil protection shelters, etc. Some of these functions may be located in the basement, others could be oriented to outdoor secondary spaces, and some may be located above the building (upper technical floor), such as technical ventilation equipments. A contemporary hotel could be compared to a cruise ship: for the ambiance to be as pleasant as possible, a true factory works in the hold. The public does not have to be aware of the activity behind the scenes.

Generally, hotels have at least two vertical circulation nodes, one for the public, with a battery of lifts and evacuation stairs, and a secondary one, with a freight elevator, for room service and emergency staircase. On each floor of the common space hall there are service rooms for staff, where the laundry and cleaning materials are stored.

The relative standardization of the accommodation units makes the hotel architecture marked by certain repetitiveness, the hotels being quite easy to spot in the landscape.

From the point of view of the architectura treatment, the hotels can have outlined certain distinctive features. They can be representative at the same time for the brand they represent and for the place where they are located. Being marked by the spirit of the place, they can be easily identified with the proposed destination. Architectural forms, materials, colors, textures, natural and artificial lighting, acoustics, tactile and olfactory stimuli, form a whole that determines the quality of the architectural experience.

From a technical point of view, in order to ensure the efficiency of the investment, the constructive solutions will be as simple and economical as possible. A logical conception of structures reduces the initial investment. The good insulation of the 
building envelope, the high efficiency of the installation equipments, the automations regarding the consumption of electricity in the absence of the users, contribute to the reduction of the building operating costs.

A good phonic insulation represents a very important aspect, regarding the comfort and offers the possibility of simultaneity of different activities.

Lectură suplimentară/ Further readings

CRISTEA ARHITECTURĂ. (2020). http://www.cristeaarhitectura.ro/ (accesat / accessed 20.02.2020)

Cristea I. (2010). Consolidare și modernizare hotel București,

fațada Calea Victoriei. Anuala Arhitectură București 2010 / 2010 Bucharest Architecture Annual.

https://www.anuala.ro/proiecte/2010/restaurari/r02/ (accesat / accessed 20.02.2020)

\section{Citare articol curent / Citation:}

(Ro)

Cristea I. (2021). Principiile arhitecturii clădirilor hoteliere. în Teoria proiectului de arhitectură. Idei construite. SP FA UAUIM. EUIM - Editura Universitară lon Mincu, București.

(En)

Cristea I. (2021). The principles of the hotel buildings' architecture. in Architectural design theory. Built ideas. SP FA UAUIM. EUIM - Ion Mincu University Publishing House, Bucharest. 
